\title{
Niespodziewane pokrewieństwo: praktyka duchowa i analityka egzystencjalna*
}

\author{
Сергей Хоружий \\ Instytut Filozofii Rosyjskiej Akademii Nauk w Moskwie (Rosja)
}

\begin{abstract}
Сергей Хоружий, Slightly unexpected relationship: spiritual practice and existential analytic, transl. ks. Łukasz Leonkiewicz, Elpis, 16 2014: 127-135.

Abstract: Existencial analytics is unquestionably a major and profound conception of constitution or of death in European thought for many centuries. We tried not only to present its structure, but made her deconstruction, in the most constructive purpose. We found that, for certain reasons and with the help of specific measures, the analyst is not only created the concept indicated, but also sought to build around her repudiation of the iron armor, which does not allow or variants, or objections, applicable to all armor uniqueness. Having destroyed the armor, deconstruction opens up the possibility of other decisions and other roads.
\end{abstract}

\begin{abstract}
Streszczenie: Analityka egzystencjalna jest bezsprzecznie główną i najgłębszą koncepcją bądź konstytucją śmierci w myśli europejskiej od wielu wieków. Spróbowaliśmy nie tylko przedstawić jej strukturę, ale dokonaliśmy jej dekonstrukcji, w najbardziej konstruktywnym celu. Odkryliśmy to, że, z konkretnych przyczyn i z pomocą konkretnych środków, analityka ta nie tylko tworzyła wskazaną koncepcję, ale i dążyła do zbudowania wokół niej pancerza żelaznej niezaprzeczalności, który nie dopuszcza ani wariantów, ani sprzeciwów, obowiązującego wszystkich pancerza wyjątkowości. Zniszczywszy ten pancerz, dekonstrukcja otwiera możliwość innych decyzji i innych dróg.
\end{abstract}

Keywords: fundamental analytics, spiritual practice

Słowa kluczowe: analityka egzystencjalna, duchowa praktyka

Badając podstawy filozoficzne ascezy hezychastycznej oraz innych szkół praktyki duchowej, dochodzimy ${ }^{1}$ do pewnej wspólnej strategii bądź paradygmatu antropologicznego, który nazywamy „paradygmatem praktyki duchowej”. U podstaw konstytucji tego paradygmatu, co postaramy się wyjaśnić ${ }^{2}$ rolę decydującą odgrywa stosunek wobec śmierci, który otrzymuje w tym wypadku konkretną, dość specyficzną formę. Chcąc zrozumieć owe struktury ustosunkowania się wobec śmierci, które znajdują się u źródeł paradygmatu Praktyki Duchowej, należy porównać je do głównych typów strukturowych sposobu odniesienia się do śmierci, które opisane zostały w tradycji filozoficznej. Pod tym kontem dokonamy poniżej szczegółowej analizy analityki egzystencjalnej Heideggera, jaką przedstawił on $\mathrm{w}$ „Byciu i czasie”.

Pierwotną sytuacją bytową „obecności” (sposobu bycia człowieka, Dasein) w jego relacji wobec śmierci jest trwoga (Angst). Nie ma potrzeby, by szczegółowo rekonstruować teraz heideggerowską strukturę koncepcji (egzystencjału) trwogi, która jest wspólnym - i ogólnie znanym - elementem całego nurtu myśli egzystencjalnej, nie tylko filozoficznej. Sednem trwogi jest drętwienie, zapaść świadomości, która w doświadczeniu śmierci stara się odtworzyć, przeżyć to, czego z zasady przeżyć się nie da: całkowitą anihilację

Tytuł oryginału brzmi: Слегка неожиданное родство: духовная практика и экзистенциальная аналитика. Artykuł umieszczony został w: С. Хоружий, О старом и новом, Алетейя, Санкт-Петербург 2000, s. 451-472.

Zob. C. Хоружий, Трилогия границы: три текста о духовной практике, [w:] С. Хоружий, О старом и новом, Алетейя, СанктПетербург 2000, s. 353-420.

2 Zob. Tamże, s. 421-450. siebie, przemienienie w Nicość. Jej główne momenty wyłaniają się jako przeciwieństwo lęku (Furcht), który jest prostą, "neontologiczną" emocją, spośród nich zwrócimy uwagę jedynie na następujące: brak konkretnego przedmiotu powodującego trwogę („przed-czym lęku jest zawsze wewnątrz-światowe... w „przed-czym” trwogi staje się jawne owo „jest niczym i nigdzie” - świat jako taki”’3); brak przedmiotu „przed którym” ogarnia trwoga („To, o co trwoga się zatrważa jest samym byciem-w-świecie"); ; wszechobecny charakter trwogi, w wyniku którego powstaje niedająca się usunąć wewnętrzna struktura, tło bycia-w-świecie („Trwoga zawsze już w sposób ukryty określa bycie-w-świecie"5), wchodzi, tym samym, w skład określających predykatów bycia-w-świecie („Trwożenie się jest jako położenie sposobem bycia w świecie"6).

Nić przewodnia wszystkich konstrukcji myśli egzystencjalnej sprowadza się do przezwyciężenia początkowej trwogi przez usensawniający wysiłek odważnego przyjęcia. Doświadczenie śmierci, jako nieodwracalne unicestwienie, należy przedstawić w nowym świetle, należy je ująć w inny sposób, nie tylko tak, by odkryło się w nim „coś pozytywnego", ale, by dostrzec w nim potencję usensawniającego źródła i centrum całokształtu doświadczenia człowieka, od którego zależeć będą pozycje jakie zajmie świadomość

M. Heidegger, Bycie $i$ czas, tłum. Bogdan Baran, Wydawnictwo Naukowe PWN, Warszawa 2010, s. 250-252. Część cytatów pochodzi z rosyjskiego tłumaczenia „Bycia i czasu” dokonanego przez Włodzimierza Bibichina, co będzie zasygnalizowane w przypisie. Spowodowane jest to różnicami, jakie pojawiają się w tłumaczeniu polskim i rosyjskim.

4 М. Хайдеггер, Бытие и время, пер. В.В. Бибихина, Москва 1997,

s. 187. Por. M. Heidegger, Bycie i czas, dz. cyt., s. 253.

5 M. Heidegger, Bycie i czas, dz. cyt., s. 256.

6 Tamże, s. 257. 
w stosunku do samej siebie oraz do świata. W tym nurcie najgłębszą i najlepiej dopracowaną jest analityka egzystencjalna Heideggera, która wykracza dużo dalej niż pozostałe w zdecydowanym twierdzeniu o centralności śmierci i pozytywnym wobec niej stosunku. Nie wdając się w szczegółową analizę tej apologia mortis, zwrócimy uwagę jedynie na to, jak wygląda, powstały pod jej wpływem, wspólny paradygmat analityki śmierci.

W konstytucji śmierci u Heideggera najważniejszą rolę odgrywa problem osiągnięcia przez obecność egzystencjału całości bytowej, „bycia-całością”. Odtwarzając znaną logikę filozoficzną, związującą ze sobą dwa pojęcia całości oraz kresu, granicy, Hiedegger wspomniany egzystencjał oraz śmierć przedstawia w koniecznej wzajemnej relacji. Argumentując to twierdzi, że zdolność bycia-całością realizowalna jest jedynie $\mathrm{w}$ „prawdziwym byciu-ku -śmierci" - w ujętym w sposób specyficzny doświadczeniu śmierci jako możliwości. Poprzez to, że doświadczenie nie obejmujące doświadczenia (bycia-ku-) śmierci zawsze zawiera element niezakończoności, niedoboru i w nim Dasein z konieczności „musi czymś jeszcze nie być”, "całość Dasein musi być ukonstytuowana przez śmierć", a struktura, fundament bycia całością określany jest przez strukturę bycia-ku-śmierci: „Struktura egzystencjalna tego bycia [bycia-ku-smierci] staje się ontologiczną możliwością Dasein w byciu całością". Następnie, dopiero w doświadczeniu śmierci Dasein odnajduje swoją wolność. $\mathrm{W}$ tym momencie argumentacja przedstawiona $\mathrm{W}$ „Byciu i czasie" odpowiada po części sposobowi ujęcia wolności przez św. Maksyma Wyznawcę: wolność bytu związana jest z aktualizacją jego własnych możliwości, jakie przynależą jedynie mu jako takiemu (por. pojęcie „woli stworzonej”,

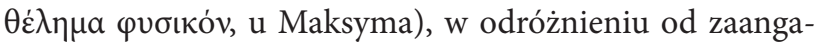
żowania $\mathrm{w}$ urzeczywistnianie możliwości przypadkowych lub narzuconych. Natomiast śmierć w analityce egzystencjalnej oraz $\mathrm{w}$ fenomenologii klasycznej traktowana jest jako subiektywna, moja śmierć, która ostatecznie odłącza i oddala Dasein (moje bycie-świadomość), jawiąc się tym samym jako maksymalnie własna, „tylko moja” możliwość. Dlatego bycie-ku-śmierci, rozumiane jako „wybieganie” (Vorlaufen) i „wybiegające zdecydowanie" - zdecydowane wstępowanie świadomości w śmierć jako możliwość, „ocala przed zagubieniem $\mathrm{w}$ przypadkowo narzucających się możliwościach” i „uwalnia siebie dla swojej własnej możliwości”, czym jest „wolne wystąpienie ku swojej śmierci”. „Wybieganie... odsłania Dasein możliwość bycia sobą... w wolności ku śmierci”’. (Właśnie wybieganie - zaznaczmy na przyszłość - utrwaliło się jako główna definicja bycia -ku-śmierci: „Bycie-ku-śmierci to wybieganie w możność tego bytu, którego sposobem bycia jest samo wybieganie"10. Śmierć-jako-wybieganie jest tą granicą z niebytem, wyłącz-

М. Хайдеггер, Бытие и время, dz. cyt., s. 245. Por. М. Heidegger, Bycie i czas, dz. cyt., s. 308.

8 М. Хайдеггер, Бытие и время, dz. cyt., s. 234.

9 М. Хайдеггер, Бытие и время, dz. cyt., s. 266. Por. M. Heidegger, Bycie i czas, dz. cyt., s. 349.

10 М. Хайдеггер, Бытиие и время, dz. cyt., s. 262. Por. M. Heidegger, Bycie i czas, dz. cyt., s. 344 nie na której Dasein może siebie dostrzec, powrócić do siebie z samo-zapomnianego sposobu bycia.

W rezultacie jako ostatni (choć nie ostatni pod względem ważności) wyróżnimy motyw autentyczności bądź własności (Eigentlichkeit, w znaczeniu właściwości). Jego pojawienie się zauważane było już w słowach: jeśli śmierć jest „moją”, własną, autentyczną możliwością, to bycie-ku -śmierci bądź „wybieganie” jest „możliwością bycia samym sobą" (por.: „W byciu-ku-śmierci Dasein odnosi się do siebie samego" ${ }^{11}$ ) czyli odnalezieniem właściwego sobie sposobu bycia, egzystencji. „W fenomenie śmierci odsłania się egzystencja... wybieganie staje się możliwe dla własnej egzystencji”'12. Jednakże sposób przedstawienia tego motywu oraz jego znaczenie jest znacznie większe. Heidegger analizuje ten motyw jako opozycję tego, co autentyczne i nieautentyczne, szczegółowo i wyraźnie rozwijając tematykę niewłaściwego doświadczania śmierci i odpowiadający mu nieautentyczny sposób bycia. Świadomości, w jej doświadczeniu powszednim, nieustannie towarzyszy tendencja ucieczki, zasłonięcia się i omijania uznania oraz dostrzeżenia śmierci w jej rzeczywistym charakterze, jako nieuniknionej i „swojej własnej” możliwości, koniecznej dla możliwości bycia samym sobą. „Zakrywające uchodzenie przed śmiercią opanowuje powszedniośćc" ${ }^{13}$, Heidegger natomiast stopniowo, szczegółowo odsłania struktury tego opanowywania. Fenomen uchodzenia czy ucieczki jest wielowątkowy, jego przejawy można zaobserwować we wszystkich sferach i wymiarach bycia Dasein. W sferze zachowań społecznych jest on opisywany znakomitym heideggerowskim pojęciem das $\mathrm{Man}^{14}$, „ludzie” (w przekładzie W. Bibichina), które wyraża bezosobowy, utarty charakter reakcji i uczynków, a nawet samej świadomości „człowieka masowego", który przyswoił sobie stereotypy otaczającego go środowiska. Tego typu błądzenie świadomości rozwija się w sferze rozumu, skrywa ono i przeinacza, skaża rzeczywisty charakter i znaczenie śmierci, przewracając ją w wydarzenie zewnętrzne (które może do ciebie przyjść, ale z zewnątrz), w "nieustannie dokonujący się przypadek", a śmierć sama w sobie przekształca się w „nieokreśloną nicość”, „sprowadzana jest do zdarzenia,... które nikogo nie dotyczy"15. W sferze emocjonalnej panuje „tchórzliwy lęk” będący wypaczeniem egzystencjalnej trwogi, która jako jedyna jest adekwatna dla zajęcia pozycji wobec śmierci. I tak dalej. Sumując wszystkie te przejawy okazuje się, że powstaje całościowy szkielet, fundamentalny obraz powszedniego bycia, który nazywany jest przez Hiedeggera „upadaniem” (Verfallen), ponieważ Dasein niewolniczo, skrępowane wszystkimi uwarunkowaniami potyka się i ześlizguje, „wpadając” w nie. Natomiast samo

\footnotetext{
${ }^{11}$ М. Хайдеггер, Бытие и время, dz. cyt., s. 252. Por. M. Heidegger, Bycie i czas, dz. cyt., s. 331.

12 М. Хайдеггер, Бытие и время, dz. cyt., s. 251, 263. Por. M. Heidegger, Bycie i czas, dz. cyt., s. 344.

13 М. Хайдеггер, Бытие и время, dz. cyt., s. 253. Por. M. Heidegger, Bycie i czas, dz. cyt., s. 333.

${ }^{14} \mathrm{~W}$ języku niemieckim man to zaimek, dzięki któremu można stworzyć niezliczone konstrukcje językowe: man spricht - „mówią”.

15 М. Хайдеггер, Бытие и время, dz. cyt., s. 253. Por. M. Heidegger, Bycie i czas, dz. cyt., s. 334.
} 
bycie powszedniości konstruowane jest jako całościowy egzystencjalny fenomen, sposób bycia Dasein - „nieautentyczne bycie-ku-śmierci". Wyklucza ono autentyczne, własne bycie-ku-śmierci lub „wybiegające zdecydowanie”, które odważnie wstępuje i utrzymuje się w doświadczeniu śmierci jako możliwości, jaka pod każdym względem jest przeciwstawiana temu sposobowi bycia.

W konsekwencji opozycja autentyczne-nieautentyczne przechodzi w pełnowartościową ontologiczną opozycję dwóch sposobów bycia Dasein. W analityce egzystencjalnej opozycja ta nie jest bynajmniej sprowadzana do prostego przeciwstawienia sobie dwóch zasad metafizycznych. Jej dodatkową cechą jest to, że bieguny opozycji nie są równowartościowe: jeden $\mathrm{z}$ nich w sposób wyraźny jest krytykowany, a drugi wychwalany, dzięki czemu opozycja ta otrzymuje aspekt aksjologiczny i etyczny. Biorąc pod uwagę tę cechę, opisywana konstrukcja ontologiczna postrzegana jako konstytutywna struktura myślenia religijnego, struktura, która łączy w sobie dwa sposoby bycia, jeden - dany, skażony, drugi - nie dany, lecz skupiający w sobie autentyczność i wartość bycia. Istnieje jeszcze inna osobliwość heideggerowskiej onto-diady, która przybliża się już nie tylko do ontologii świadomości religijnej, ale i mistycznej. Pomiędzy dwoma sposobami bycia ma miejsce wzajemna relacja o procesualnym i dynamicznym charakterze. W jeden nieautentyczny sposób opisywany jako „upadanie” Dasein jest pierwotnie zanurzone. Jednak ten początkowy status nie może pozostać niezmieniony. Analityka egzystencjalna otwiera przed Dasein zadanie bycia, przeznaczenie, polegające na rozpoznaniu własnego niewłaściwego bycia-ku-śmierci w jego niewłaściwości, odrzuceniu jego i skonstruowaniu innej podstawy dla bycia, właściwego bycia-ku-śmierci. Dlatego od razu zauważamy, że proces ontologiczny, który miałby być realizacją tego zadania, w swej strukturze przynależy do konkretnego typu: jest to właśnie taki proces, który wypracowany został $\mathrm{w}$ (mistyczno-ascetycznych) praktykach duchowych. Już wcześniej dokonaliśmy ogólnego opisu paradygmatu Praktyki Duchowej, wydzielając jej główne elementy strukturalne. Porównanie z tym paradygmatem procesu odnalezienia przez bycie-świadomość właściwego bycia-ku-śmierci umożliwia nowe spojrzenie na koncepcję śmierci w analityce egzystencjalnej.

Znaleźliśmy się oto w obrębie tej samej, tradycyjnej już i dużo wcześniejszej, niż analityka Hiedeggera, tematyki związanej z zaczynającą się u Platona myślą o filozofii jako nauce umierania, „ćwiczenia się w umieraniu”. Nie tak dawno Pierre Hadot ponownie prześledził tę tematykę w myśli antycznej, a po części również nowożytnej, przedstawiając ją jako przykład ogólnego paradygmatu „ćwiczeń duchowych". Opisuje je jako paradygmat aktywnej samorealizacji człowieka, ukierunkowany ku uporządkowanej pod względem metodycznym autoprzemianie, która porusza "nie tylko myśl, ale i całą psychikę (le psychisme) indywiduum” oraz zakłada „transformację sposobu widzenia świata i przemianę (une metamorphose) osobowości"16.

16 P. Hadot, Exercices spirituels et philosophie antique, Paryż 1981, s. 26
Idea takiej aktywności charakterystyczna jest dla rozumu antycznego. Graniczy ona bezpośrednio z jednym z jego fundamentalnych założeń, dotyczaccego konieczności kultu, uprawiania człowieczeństwa człowieka, wyrażonego przez słynny paradygmat wychowania, paideia; tak więc paradygmat „ćwiczeń duchowych" może być traktowany jako modyfikacja paradygmatu wychowania, która ukierunkowuje ten paradygmat na samowychowanie. Nie ma on jedynie czysto intelektualnego charakteru, ale nie jest też całkowicie holistyczny, ponieważ w jego skład nie wchodzi cielesność, a „ćwiczenia duchowe" nie odwołują się wcale do jakiegokolwiek cielesnego czy fizycznego elementu. Mamy zatem przed oczami duchowo-psychiczny paradygmat, który odpowiada myśleniu platońskiemu z jego dualistyczną antropologią (mimo iż a priori nie musi być ona ograniczona tym myśleniem). Ideą charakterystyczną również dla kultury antycznej, a nie raz spotykaną również w myśli późniejszej, jest myśl o tym, że stosunek człowieka do śmierci powinien przybierać podobną formę ćwiczenia, przy czym pojawiające się ćwiczenie duchowe, „ćwiczenie się w umieraniu", jest niczym innym, jak filozofowaniem: prawdziwe filozofowanie jest tym, czym filozofia być powinna. Pierwszy raz idea ta w sposób jasny i zdecydowany wyrażona została $\mathrm{w}$ „Fedonie”, następnie rozwinięta w „Państwie”, by najmocniej dać o sobie znać w późniejszej myśli - u stoików; analitykę Heideggera Hadot również zalicza do tego nurtu. Mamy do tego wystarczająco dużo podstaw: wszystkie główne elementy heideggerowskiej apologia mortis - powiązanie doświadczenia śmierci z autentycznym sposobem bycia, $\mathrm{z}$ wolnością, $\mathrm{z}$ osiągnięciem bycia $\mathrm{w}$ jego całości - bez problemu odnajdziemy u stoików, Platona, a kluczowe pojęcie „wybiegania”, Vorlaufen, stanowiące rdzeń autentycznego bycia-ku-śmierci, jest jedynie wariantem stoickiej zasady praemeditatio malorum (uprzednie-przygotowujące przeżywanie zła).

Jak widzimy analitykę śmierci można przyrównać do paradygmatu „ćwiczeń duchowych”, lecz chcemy powiedzieć o niej coś więcej. Pomiędzy nią a paradygmatem „Praktyk Duchowych”, jak jest on przez nas rozumiany, istnieje zasadnicza różnica w aspekcie ontologicznym. W tym aspekcie paradygmat bądź strategia „ćwiczeń duchowych” nie odróżnia się od strategii wychowania: obie one ukierunkowane są ku odsłonięciu, realizacji człowieczeństwa człowieka, jego pierwotności, jako jego prawdziwej natury, niech nawet realizacja ta będzie rozumiana nie jako prosty rozwój organiczny, lecz jako głęboka przemiana, transformacja osobowości dokonująca się przez potępienie i odrzucenie wielości w człowieku, pozbawienie sie „dzikiej części duszy" (Platon) itp. Oznacza to, że transformacja urzeczywistniająca się w „ćwiczeniu duchowym” nie jest transformacją ontologiczną; będąc bardzo blisko sfery doświadczenia ascetycznego i mistycznego, „ćwiczenie duchowe” nie musi przekraczać ich granic. Jednakże praktyka duchowa jest właśnie praktyką mistyczno-ascetyczną, która dąży do bardziej fundamentalnej transformacji, w ściśle ontologicznym sensie, w której dokonuje się nie realizacja, lecz przezwyciężenie i przemiana pierwotnej natury człowieka, samej jego obecności bądź horyzontu bycia w określających 
go predykatach. Dlatego, mimo iż pod względem ogólnym te dwa paradygmaty są sobie bardzo bliskie - dotyczą dynamicznych, czynnych, procesualnych strategii antropologicznej samorealizacji, powstały $\mathrm{z}$ refleksji i samoorganizacji, - to w przypadku paradygmatu Praktyki Duchowej ostateczny stan, telos praktyki jako procesu antropologicznego, powinien być bardziej radykalny, powinien różnić się pod względem ontologicznym i być bardziej skrystalizowanym niż stan początkowy. Wskutek tego sam proces powinien odpowiadać surowszym i bardziej specyficznym warunkom i wymogom. U jego podstaw znajduje sie wyraźnie wyrażony impuls, odtrącenie i ucieczka, całościowe odrzucenie początkowej natury i sposobu bycia. Impuls ten jest klasycznym, fundamentalnym elementem ascezy, opisywany jest przez ascetyczne koncepcje: „świata”, pokuty, skruchy, nawrócenia. Następnie, część centralna, jeśli ma prowadzić do aktualnej transformacji ontologicznej, powinna być osadzona na konkretnych, jednoznacznych stopniach, po których możliwy jest ruch; unikalność stojącego przed nami celu ontologicznego implikuje unikalność drogi ku niemu („ćwiczenia duchowe" określane są raczej w ogólnych charakterystykach i zarysach, a nie w jednoznacznych i konkretnych regułach). I wreszcie, last but not least, osiągnięcie transformacji ontologicznej wymaga uczestnictwa czynników przynależących do innej natury (poza-, nad-naturalnych), źródło których jest poza wyjściowym horyzontem bycia, przez co nie mogą być ani dostarczane, ani kierowane przez samego człowieka, ale mogą być odnajdywane w horyzoncie jego doświadczenia jedynie jako przejawy spontaniczne, nie posiadające identyfikującego je źródła empirycznego. Okazuje się zatem, że konceptualny obraz praktyki duchowej z konieczności musi włączać w swój obręb znajdujące się na zewnątrz Źródło oraz pewną więź z nim, która jest decydująca dla realizacji ponadempirycznego telosu praktyki i która przynależy już, w pełni bądź częściowo, do specyficznej sfery doświadczenia mistycznego. Natomiast sam telos można opisać jako pewien rodzaj zjednoczenia ze znajdującym się na zewnątrz Źródłem; najbardziej rozwinięte praktyki, którym dostępne, w pewnej mierze, jest to zjednoczenie, odkrywają, że nie oznacza ono utożsamienia się ze Źródłem $\mathrm{w}$ jego istocie, lecz jest zjednoczeniem się z jego przejawami, energiami.

Porównanie analityki śmierci z przedstawionym paradygmatem lepiej wyjaśnia jej istotę i specyfikę, niż porównanie do „ćwiczeń duchowych”; w konkretnych aspektach osiągana jest w nim, co jeszcze zobaczymy, dekonstrukcja tej analityki. Główne elementy tego porównania struktur konceptualnych zostały już przedstawione wyżej. Stan pierwotny, pozycja wyjściowa procesu ontologicznego określana jest mianem „bycia powszedniego”; określa ono „niewłaściwe bycie-ku-śmierci" i charakteryzuje się bogatym zasobem cech, które wyrażają pustkę i nieautentyczność danego sposobu bycia w jego wszelakich aspektach: „zagubienie w Się”, podporządkowanie „gadaninie, ciekawości i dwuznaczności”, „tchórzliwy lęk” itd. Tylko co przytoczyliśmy te określenia, które tworzą analogię do ascetycznego pojęcia „świat", analogia pojawia się także przy innych opisach (np. przy „upadaniu”), a pojęcie „świat” staje się, zgodnie z zasadami analityki Heideggera, pełnowartościowym pojęciem ontologicznym. Już podkreśliliśmy, że całkowity opis „powszedniego bycia” dokonany jest za pomocą pojęć negatywnych, w negatywnej, krytyczno-potępiającej całości. Jest to kolejny element dyskursu ascetycznego - tematyka demaskacji „świata”, rezygnacji; następnie tak u Heideggera, jak i w dyskursie ascetycznym demaskująca mowa, wyrażenie rezygnacji w sposób logiczny i nieuchronny przemienia się $\mathrm{w}$ stwierdzenie pewnych już pozytywnych zadań bycia.

W tym miejscu rozpoczyna się paralela z główną częścią paradygmatu Praktyki Duchowej, która również jest konkretna i można ją prześledzić. W tej części paradygmatu (procesu) konieczne są, przede wszystkim, czynniki dynamiczne, które zabezpieczą stopniowy ruch procesu; w analityce egzystencjalnej natomiast w centralnej części konstytucji właściwego bycia-ku-śmierci, odnajdujemy odgrywające taką właśnie rolę egzystencjały zdecydowania i sumienia. Sumienie charakteryzowane jest jako zasada pobudzająca, wzywająca i poruszająca: „Analiza sumienia odsłania je jako zew... Zew sumienia posiada charakter wezwania obecności do jej najbardziej własnej zdolności bycia samym sobą" ${ }^{17}$, tzn. wezwania do budowania autentycznego doświadczenia śmierci jako możliwości. Zdecydowanie opisane jest jako czynnik nie mniej dynamiczny: „Milczące, gotowe do trwogi projektowanie się na najbardziej własne bycie winnym - nazywamy zdecydowaniem"18. Zaznaczona w tym miejscu więź z trwogą wskazuje na to, że zdecydowanie posuwa i wprowadza w zdecydowaną i kończącą sferę procesu ontologicznego, aż do wybiegania w śmierć jako możliwość (co i jest nazywane „wybiegającym zdecydowaniem").

W tej sferze końcowych etapów procesu obraz zgodności konceptualnych może wydać się zaskakujący na pierwszy rzut oka. W rzeczywistości, to właśnie w tym miejscu zgodność przekształca się z banalnej w pouczającą, a nawet dekonstrukcyjną. Główne elementy konstytutywne danej sfery - coraz wyraźniejsze działanie czynników spontaniczności, pochodzących z położonego na zewnątrz Źró$\mathrm{dka}$, a nawet sam telos procesu, czyli aktualna przemiana ontologiczna natury pierwotnej - porównane mogą być do „wyższych stanów duchowych" w praktyce duchowej. Niezależne od człowieka działanie, które spełnia rolę głównej i koniecznej przesłanki ontologicznej transformacji obecne jest również u podstaw analityki egzystencjalnej, a jest tym nie co innego, jak trwoga. Chcąc obronić to stwierdzenie powinniśmy wykazać, że trwodze przysługują dwie cechy: spontaniczność (niezależność od świadomości i woli) i decydująca rola przy osiągnięciu telosu procesu. W heideggerowskiej analityce trwogi te cechy są nie tylko obecne, ale pełnią także główną rolę. Wyrażane są one w specyficznym języku tej analityki: pierwsza cecha zachowuje swą ważność dlatego, że trwoga jest fenomenem źródłowym (ursprunglichste), a druga poprzez to, że jest fenomenem otwierającym (erschließende).

\footnotetext{
17 М. Хайдеггер, Бытие и время, dz. суt., s. 269.

18 Tamże, s. 297. Por. M. Heidegger, Bycie i czas, dz. cyt., s. 388.
} 
Powyżej w skrócie opisaliśmy ten kluczowy element doświadczenia śmierci, odkrywając, że jego istota prezentuje stan (w sensie hiedeggerowskim), który odpowiada wydarzeniu spotkania świadomości ze śmiercią, jako wydarzeniu zbliżającemu się (lecz nie osiągającemu „klasycznej pełni”) do zapaści, paraliżu świadomości. Jednak na tym w analityce egzystencjalnej rola trwogi się nie kończy. $\mathrm{W}$ stosunku do analizowanego procesu ontologicznego ta paraliżująca rola odpowiada jedynie początkowi, etapowi „powszedniego bycia”. Jednakże następnie podczas całego procesu dokonuje się przemiana relacji świadomości i trwogi. Przemiana ta jest kardynalna, głęboka, choć niezmienną pozostaje sama natura trwogi jako fenomenu ontologii fundamentalnej. Stan poczucia trwogi pozostaje „jednym z zasadniczych sposobów bycia-w-świecie”, pierwotnym elementem sytuacji bytowej człowieka, co i jest wyrażane przez heideggerowski predykat „źródłowości”, Usprunglichkeit. Ontologiczna charakterystyka trwogi koreluje, na poziomie psychologicznym, z konieczną dla nas cechą - sponatanicznością. Ani wola, ani rozum nie decydują czy człowiek (Dasein) ma przyjmować pozycję zatrwożenia przy spotkaniu świadomości ze śmiercią, pojawia się ona niezależnie, niesamowolnie, spontanicznie. Ten aspekt spontaniczności trwogi wzmacnia i szczegółowo ukazuje odsłaniający trwogę egzystencjał „nieswojości” i inne. Jako porównanie należy zwrócić uwagę na to, że w terminach paradygmatu Praktyki Duchowej trwoga (jak i wszelkie położenie) jest fenomenem energicznym, transportującym określone energie. Pojawia się ona niezależnie od człowieka i zmienia jego „położenie”, czyli konfigurację (ponownie położenie!) jego energii, jego „energiczny obraz”. Oczywistym jest, iż ta zdolność oddziaływania na energie człowieka oznacza, że trwoga włada własną energią, niesie w sobie bądź prezentuje przez siebie pewne „energie trwogi”.

Kolejnym ważnym dla nas momentem jest poruszające ku telosowi działanie trwogi, które pojawia się w wyniku przemiany, jaka dokonuje się w relacji świadomości i trwogi $\mathrm{w}$ toku procesu ontologicznego. Wraz $\mathrm{z}$ wstąpieniem $\mathrm{w}$ proces, $\mathrm{z}$ rozpoczęciem przezwyciężania niewłaściwego bycia-ku-śmierci konstytuuje się, co już zauważyliśmy, zdecydowanie i sumienie (zew). Dostrzegliśmy również, że zdecydowanie jako egzystencjał zawiera gotowość, przygotowanie do trwogi; dla Dasein, które przeniknięte jest trwogą, działanie trwogi nie jest przyczyną paraliżu i zapaści, powoduje coś wręcz przeciwnego. Trwoga staje się „trzeźwą trwogą, która umożliwia jeden sposób bycia”. Oznacza to, że świadomość przeżywa nawrócenie (w czym widzimy kolejny ważny i wspólny element z paradygmatem Praktyki Duchowej): działanie trwogi staje sie dla niej już nie paraliżujące i zamykające drogę, lecz „otwierające”, tzn. odsłaniającym drogę działaniem owocnym pod względem ontologicznym. Ponadto spośród wszystkich czynników otwierających (a zaliczyć do nich można na przykład jakiekolwiek położenie, ponieważ „do istoty wszelkiego położenia należy otwieranie bycia-w-świecie"19) trwoga jest otwierającą par excellence, ponieważ jej położenie

19 М. Хайдеггер, Бытие и время, dz. суt., s. 190. jest "położeniem fundamentalnym” otwierającym „skrajną możliwość": pociąga Dasein bezpośrednio ku bytowej autentyczności, ku telosowi. „Trwoga wyciąga Dasein z jego upadającego rozproszenia w świecie...Trwoga przed śmiercią jest... odkryciem tego, że Dasein egzystuje ku swemu końcowi... Nastrojony przez trwogę zew daje możliwość Dasein rzucenia się na swoją własną zdolność bycia”20 wszystkie te formuły wyrażają jedno i to samo - nawrócona świadomość, która odnalazła zdecydowanie i zew, jest poruszana przez trwogę i kierowana ku autentycznemu, poszukiwanemu sposobowi bycia. Poprzez działanie trwogi urzeczywistnia sie telos, „swoja własna zdolność bycia”, właściwe bycie-ku-śmierci. Nie tylko „trwogą”, przez trwogę, lecz już w samej trwodze, telos i trwoga zbliżają się maksymalnie, likwidując wszelką odległość między sobą. „Bycie-ku-śmierci jest z istoty trwogą"21.

Tak więc: jeżeli analityka egzystencjalna jako fenomenologiczna deskrypcja samorealizacji Dasein w ontologicznym procesie osiągnięcia właściwego sposobu bycia-ku -śmierci w swej strukturze odtwarza (o czym się już prawie przekonaliśmy) paradygmat Praktyki Duchowej, to w pojawiającej się realizacji paradygmatu w roli energii położonego na zewnątrz Źródła, urzeczywistniających ontologiczną transformację, pojawiają się energie trwogi. Własne energie człowieka (Dasein - obecności) powinny zostać „nastrojone przez trwogę” (zob. wyżej), a mówiąc w języku paradygmatu Praktyki Duchowej powinny one dążyć do osiągnięcia synergii z trwogą. Jednakże chcąc, by porównanie to otrzymało ostateczną jasność, należy jeszcze wyraźniej przeanalizować sam telos. Przyjrzawszy sie mu blisko okazuje się, iż posiada on swoją strukturę, u jego podstaw możemy wyróżnić cały szereg następujących poziomów: 1) sam finalny sposób bycia Dasein - „wybiegające zdecydowanie”, zdecydowane wybieganie w śmierć jako „swoją własną" możliwość; 2) konieczna przesłanka danego sposobu bycia - sama śmierć-jako-możliwość, śmierć-świata-jakodoświadczenia (Dasein); 3) konieczna przesłanka powyższej przesłanki - śmierć jako taka bądź całkowite unicestwienie, unicestwiająca Nicość. Taka właśnie struktura dokładnie odpowiada paradygmatowi Praktyki Duchowej, dzięki czemu naszemu porównaniu możemy ostatecznie dopisać kropkę nad „i”. Na tym etapie będziemy posługiwać się językiem hezychastycznego urzeczywistniania paradygmatu, w którym rozwinięta została wygodna sieć pojęciowa; poruszać jednakże będziemy wyłącznie uniwersalne, a nie ograniczone przez hezychazm, kwestie.

Zdecydowane wybieganie w śmierć-jako-możliwość jest, co podkreśliliśmy, przyjęciem trwogi i wstępowaniem w nią jako w „trzeźwą trwogę, która umożliwia jedyną możliwość bycia”, co z kolei oznacza współorganizację i połączenie (synergię) z trwogą jako czynnikiem energicznym, $\mathrm{z}$ jej energiami. Ponadto na mocy spontaniczności trwogi jej energie, które przyciągają Dasein ku telosowi procesu, pojawiają się jako niezależne od Dasein, posiadają inne, au-

\footnotetext{
20 Tamże, s. 189, 254, 277.

${ }_{21}$ М. Хайдеггер, Бытие и время, dz. суt., s. 266. Por. M. Heidegger, Bycie i czas, dz. cyt., s. 348.
} 
tonomiczne źródło. Tym samym, posługując się pojęciami paradygmatu Praktyki Duchowej, występują one jako energie położonego na zewnątrz Źródła, a korzystając z terminologii hezychastycznej - jako energie boskie bądź łaska. To znaczy, że osiągany sposób bycia w analityce egzystencjalnej jest dokładnie tym samym, czym telos w paradygmacie Praktyki Duchowej; zdecydowane wybieganie w śmierć-jako-możliwość jest niczym innym, jak całościowym zjednoczeniem energicznym, zjednoczeniem wszystkich energii człowieka (Dasein) z energiami trwogi, rozumianych jako energie położonego na zewnątrz Źródła, co w języku hezychazmu nazywane jest Przebóstwieniem. W tym kontekście możnaby zmodyfikować przytoczoną powyżej formułę Heideggera, mówiąc: Bycie-ku-śmierci jako energiczne jest trwogą. Następnie, śmierć-jako-możliwość jako egzystencjał, jako przynależność do świata-jako-doświadczenia, jest nie tylko reprezentowana przez trwogę, lecz utożsamia się z nią, pojawiając się jako czynnik energiczny, zjednoczenia z którym poszukuje i które osiąga wybieganie, tzn. śmierć również pojawia się jako energia położonego na zewnątrz Źródła bądź energia boska. Na koniec pozostała jeszcze jedna ostatnia logiczna i ontologiczna przesłanka. Śmierć jako Unicestwiająca Nicość, czym jest także (moja) śmierć jako aktualna faktyczność (mojego doświadczenia), śmierć, która już nastąpiła, nie znajduje się już ani w horyzoncie własnego bycia-ku-śmierci, ani w ogóle w horyzoncie (mojego, subiektywnego) doświadczenia, lecz znajduje się poza tymi horyzontami, będąc jednocześnie dla nich konstytutywną. Podobieństwo jest dość wyraźne: w paradygmacie Praktyki Duchowej to miejsce zarezerwowane jest dla Boga - dla rzeczywistości boskiej w sobie, ad intra (w neoplatonizmie - Jedni, a w hezychazmie - niepoznawalnej Istocie Boga).

Ta końcowe podobieństwo nadaje ostrości całemu obrazowi. Analityka egzystencjalna przedstawiona została, bowiem, jako przykład, jako jeden ze sposobów realizacji paradygmatu Praktyki Duchowej, który posiada całą strukturę danego paradygmatu, zasadniczo i rażąco się jednak odróżniając od przykładów klasycznych. Różnica ta, mówiąc bardzo ogólnie, jest wręcz wyraźnym przeciwieństwem, inwersją. Transformacja ontologiczna, która poszukiwana i praktykowana jest $\mathrm{w}$ tradycjach mistycznych i mistyczno-ascetycznych, niezmiennie traktowana była jako ontologiczne wstępowanie, przemienienie $\mathrm{w}$ innobyt, uwolniony od niedoskonałości bytu doczesnego i niosący w sobie pełnię bycia. Ta ostatnia zawsze pojmowana była jako doskonałe boskie bycie, a, co wykazaliśmy wyżej, w paradygmacie Praktyki Duchowej „pozakadrową" instancją ontologiczną, która konstytuuje i warunkuje cały proces ontologiczny jest Bóg. Jednak w analityce egzystencjalnej miejsce Boga zajmuje Śmierć jako Unicestwiająca Nicośćc ${ }^{22}$, a osiągnięcie autentycznego bycia zastąpione jest

\footnotetext{
${ }^{22}$ W praktykach dalekowschodnich, jak wiadomo, telos porównywany jest $\mathrm{z}$ horyzontem ontologicznym, posiadającym cechy niebytu, chociaż nie ma między nimi pełnej adekwatności. Jednak nie można twierdzić, że poprzez to zbliżają sie one do analityki egzystencjalnej (w odróżnieniu od stanowiska późnego Heideggera); telos praktyki przecież nie jest związany ze śmiercią. Można byłoby raczej powiedzieć, że jako telos
}

zjednoczeniem z energiami śmierci, całkowitym przesiąknięciem śmiertelną trwogą. W stosunku do czysto chrześcijańskiego, hezychastycznego sposobu realizacji praktyki duchowej, praktyki Przebóstwienia, tego typu struktura jest ewidentną inwersją; praktyka, kultywująca doświadczenie Nicości, może być nazwana praktyką anty-przebóstwiejącą. Porównując ją z neoplatońskim wstępowaniem ku Jedni również dostrzegamy między nimi dość wyraźną i oczywistą sprzeczność.

Bliska więź analityki egzystencjalnej z dyskursem teologicznym, a dokładniej chrześcijańskim, stanowi już starą i obszerną tematykę, która znajduje się wciąż na powierzchni, nie jest głęboko ukryta. Jak wiadomo już nieraz o tym dyskutowano, a sama ta więź jest wrodzona i źródłowa. Przecież sam zamysł i główne idee „Bycia i czasu” zaczerpnięte zostały nie tylko $\mathrm{z}$ fenomenologii, lecz również z bliskich kontaktów z teologią protestancką, a przede wszystkim z osobistej znajomości z Rudolfem Bultmanem. Podobieństwa teologiczne, struktura teologiczna w konstrukcjach analityki egzystencjalnej nie raz zauważane były przez samego autora, natomiast jeszcze więcej ukazali ich późniejsi badacze, tak więc ogólny charakter całego kompleksu związków z teologią był wystarczająco wyraźny. Pod względem ideowym i metodologicznym charakter ten przypomina podjętą przez Bultmana próbę demitologizacji i może być postrzegany jako swego rodzaju jej korelat w dyskursie filozoficznym: logika, koncepcje i paradygmaty myśli teologicznej zostają wyłączone, unoszą się ze swego kontekstu kerygmatycznego i dogmatycznego, oczyszczają się od wszystkich konotacji religijnych, innymi słowy, następuje ich sekularyzacja, po czym wykorzystane zostają w filozofii. Zgodnie z tym, na co wskazuje Heidegger i z czym możemy się zgodzić, taką ostrą reinterpretację struktur myślowych można uznać za redukcję fenomenologiczną, epoche. Czy można jednak odkryta przez nas zgodność odnieść do tej kategorii? Nie dokonawszy konkretnej analizy, zatrzymawszy się na ogólnym wrażeniu można udzielić odpowiedzi negatywnej. Zgodność z praktyką duchową nie dotyczy tylko jakichś pobocznych wątków, lecz odnosi się wprost do rdzenia analityki egzystencjalnej zarówno pod względem logicznym, jak i egzystencjalnym; dotyczy jej życiowego nerwu i patosu, tego, co ma przekazać, message. Ponadto inwersja, jako zamiana na to, co odmienne i przeciwne, jest całkowicie inną modyfikacją materiału, niż zwykła dyktowana przez poprawność filozoficzną reinterpretacja, powstrzymanie się od wszystkiego, co dowolne i nieudowadnialne, a co niesie ze sobą „zaangażowana” świadomość religijna. Za tym radykalnym przewrotem paradygmatu stoi coś innego, niż prosta wierność metodzie filozoficznej i filozoficzny brak uprzedzeń. Cóż to takiego?

Poszukując odpowiedzi zauważamy, przede wszystkim, że analityka egzystencjalna w swej ogólności rozpa-

występuje sposób bycia, w którym życie jest nieodróżnialne od śmierci, a taki sposób bycia odległy jest od „zdecydowanego wybiegania w śmierć”, które z kolei nacechowane jest maksimum intensywności życia: „Najbliższa bliskość bycia śmierci-jako-możliwości jest maksymalnie odległa od śmierci rzeczywistej”. М. Хайдеггер, Бытие и время, dz. суt., s. 266. 
trywana jest w dyskursie, któremu daleko do „filozoficznego braku uprzedzeń”. Mówiąc o niej, nieprzypadkowo użyliśmy słów „patos” i „przekaz”, ponieważ te elementy wyraźnie są w nim wyrażone. Jednym z głównych jej pojęć roboczych (egzystencjałów) jest „położenie”, Befindlichkeit, rozumiane jako nastrój emocjonalny, afektywność; ona nie tylko mówi o położeniu, ona jest nim obdarzona. Analityka egzystencjalna posiada całe spektrum własnych ukrytych $w$ tekście położeń. W celu jej zrozumienia korzystnym będzie ich odsłonięcie, ale chcąc to osiągnąć potrzebna jest analiza sposobów działania, środków wyrażających, jakie wykorzystane zostały w dyskursie „Bycia i czasu”. Analiza taka może okazać się owocną i pouczającą, ponieważ okazuje się, że dany dyskurs skrywa w sobie bogaty repertuar środków dyskretnego oddziaływania na czytelnika - różnorodnego oddziaływania, które bynajmniej nie ogranicza się jedynie do oddziaływania emocjonalnego (położenia), lecz odgrywa wielką rolę w wypełnieniu znaczeniowych zadań tekstu, w przekonaniu do jego idei, dopełniając znacząco zwykłe i jawne środki argumentacji filozoficznej. Teraz jednak nie będziemy zagłębiać się w tę analizę, dokonamy jedynie kilku uwag, które w sposób bezpośredni związane są z naszym tematem - interpretacji analityki śmierci pod kontem jej zgodności z paradygmatem Praktyki Duchowej.

Najbliżej dyskursu są środki oddziaływania emocjonalnego. Dyskurs „Bycia i czasu” często korzysta z leksyki ekspresyjnej, o zabarwieniu emocjonalnym, a wykorzystanie jej, o czym z łatwością możemy się przekonać, podporządkowane jest zadaniom znaczeniowym. Wyrażane jest to w ten sposób, iż leksyka emocjonalno-ekspresyjna koncentruje się masowo w konkretnych miejscach tekstu. Jeden $\mathrm{z}$ wyraźnych tego przykładów dotyczy akurat interesującej nas tematyki. Jedną $\mathrm{z}$ takich koncentracji masowych jest $\$ 51$ „Bycie-ku-śmierci i powszedniość Dasein”. Opisywane jest w nim bycie powszednie, nieautentyczne bycie-ku-śmierci i da się zauważyć, że dyskurs opisujący tę nieautentyczność korzysta nie tylko $\mathrm{z}$ argumentacji filozoficznej, lecz, chyba nawet bardziej, ze środków emocjonalno-psychologicznych. Codzienny stosunek wobec śmierci opisywany jest od początku prawie wyłącznie barwnymi pojęciami oceniającymi, np.: umieranie „wypacza się” (verkehrt wird) i „niweluje” (nivelliert wird); śmierć „wydaje się” być czymś, czym nie jest, jej prawdziwy charakter „jest ukryty” (verhullt); człowiek „chowa przed sobą” (sich verdeckt) „swoje własne” (eigenste) bycie; bliscy „wmawiają” (einreden) umierającemu fałszywą sytuację, „mniemają”, że go „pocieszą". Oddzielne demaskacje sprowadzają się do rytmicznych formuł obwiniających: „skryta ucieczka przed śmiercią uparcie panuje...”, a ton oryginału jest jeszcze bardziej nieubłaganie-metaliczny: „Das verdeckende Ausweichen vor dem Tode beherrscht die Alltäglichkeit so hartnäckig.... Mocnym środkiem mającym przekonać do nieautentyczności jest, co wiadomo retoryce, cudzysłów („pocieszenie”, „zatroskanie”...) - dzięki czemu fałsz, imitacja tej relacji pojawia się dość wyraźnie. Wszystkie te przykłady wzięte są z jednej strony tekstu, także pod względem koncentracji środków słusznie możemy mówić o ataku psychologicznym, który dokonuje się przy pomocy wyraźnego systemu dyskursu.

Tego typu atak stanowi jeszcze jedną wspólną cechę analityki egzystencjalnej i praktyk duchowych. Powyżej podkreśliliśmy, że w paradygmacie Praktyki Duchowej etapem początkowym jest wyraźne ukazanie i całkowite wyzbycie się, odrzucenie zastanego sposobu bycia, „świata”, co nazwać można szczególnym szokiem dla świadomości, który wyrywa ją spod władzy stabilności i rutyny. Etap ten stanowią „pokuta” i „nawrócenie”, które są kamieniem węgielnym ascezy, dzięki czemu dyskurs ascetyczny swoje cele osiąga, w pierwszej kolejności, nie na drodze rozważań filozoficznych, lecz poprzez działanie emocjonalno-psychologiczne, które wykorzystane może zostać w szerokim repertuarze $^{23}$. Wyeksponowana cecha analityki egzystencjalnej ponownie wskazuje na zgodność z paradygmatem Praktyki Duchowej. Okazuje się, że w ramach dopełnienia struktury logicznej i konceptualnej taka zgodność pojawia się również w innych sferach dyskursu - „położenia”, w emocjonalno-psychologicznym spektrum i środkach jego przekazu (mimo iż w ascezie pozanaukowe rodzaje dyskursu - retoryka, homilia, narracja, - zajmują o wiele ważniejsze miejsce). Jeżeli zgodność dotyczy nie tylko strony formalno-strukturalnej, lecz ma charakter całkowity, globalny, to ten globalny charakter odkrywa przed nami ukryte warstwy analityki egzystencjalnej, głębię jej motywacji i wewnętrzny patos.

Możemy teraz powiedzieć, że analityka egzystencjalna nie odpowiada pod względem struktury paradygmatowi Praktyki Duchowej, lecz jest praktyką duchowa. Ściślej mówiąc, stawia ona przed sobą zadanie należące do dyskursu praktyki duchowej, polegające na tym, że służyć ma nie tylko celom życiowo-praktycznym, urzeczywistnianiu pewnego sposobu samorealizacji człowieka (jak dyskurs ćwiczeń duchowych), lecz ma być drogowskazem wskazującym w jaki sposób dokonać aktualnej transformacji ontologicznej. Jest to, w ścisłym sensie, zadanie czysto mistyczne, które nadaje dyskursowi wiele specyficznych cech, takich jak naprężenie doświadczenia granicznego, wewnętrzny patos podążania ku Nieobecnemu Telosowi. Oczywiście przypisane jest jej również zadanie filozoficzne, którego, w odróżnieniu od zadania mistycznego, nie mamy potrzeby objaśniać, ponieważ jest ono wyeksponowane wyraźnie przez nią samą. Zadanie to zostało postawione $\mathrm{w}$ ramach fenomenologii, niosąc w sobie jej immanentny patos „tu-stronnej” deskrypcji i stanowcze powstrzymanie się od jakiegokolwiek domysłu i „mistycznej dowolności”. Tak więc w zetknięciu się dwóch zadań i dwóch patosów, jawnego i ukrytego, konstytuuje się porażające nas rozwiązanie: inwersja starożytnego, klasycznego paradygmatu doświadczenia duchowego i uznanie za telos dynamiki ontoantropologicznej Nicości, Śmierci i Trwogi. „Pragnienie autentycznego bycia” - w ten sposób często nazywano ten zamiar, który realizowany jest w praktyce duchowej i doświadczeniu mistycznym; a, podążając za rozwiązaniem swego zadania mistycznego, analityka egzystencjalna stara się urzeczywistnić to pragnienie

\footnotetext{
23 O analizie fenomenu pokuty przeczytać można w książce: C. Xopyжий, К феноменологии аскезьь, Москва 1998, ч. II, разд. II-VI.
} 
w całej jego autentyczności i powadze, nie zamieniając i nie redukując jej natury ontologicznej. Podążając jednak za postawionym przed nią zadaniem fenomenologicznym, dokonuje ona przeorientowania tego pragnienia: odczytuje i rozumie swój telos w sposób całkowicie odwrotny.

Wpływ i ślady dyskursu praktyki duchowej odnaleźć można również w wielu innych aspektach i na przykładzie wielu niuansów analityki egsystencjalnej. Nie będziemy ich teraz analizować, z wyjątkiem jednego, który istotny jest dla rozumienia samej praktyki duchowej. Dyskurs praktyki duchowej posiada, co już powiedzieliśmy, zadania życiowo-praktyczne, które są skrajnie maksymalistycznymi. W odróżnieniu od zadań stawianych przed dyskursem filozoficznym, nie musi on opisywać konkretnych fenomenów bądź uzasadniać pewnych pozycji, musi on raczej pobudzić, poruszyć ku radykalnej przemianie i zaprezentować konkretną drogę, strategie i cel (telos) tej przemiany - w postaci jedynej drogi, jedynej strategii i jedynego celu. W tym celu powinien być to dyskurs woli, który nie tylko opisuje i nie zajmuje się wyłącznie przekonywaniem, lecz zmusza i popycha, władczo zniewala, uparcie przekonuje do wyjątkowość drogi i celu... W tym miejscu oddala się on od dyskursu filozoficznego; z pozycji filozofii, takie cechy charakteryzują dyskurs totalitarny, który manipuluje świadomością i który jest z góry podejrzany w swych stwierdzeniach i wywodach, ponieważ dochodzi do nich posługując się środkami niefilozoficznymi. W analityce egzystencjalnej znajdujemy wszystkie te totalitarne elementy. Przejawy dyskursu totalitarnego, dyskursu władzy, siłowego i wolicjonalnego oddziaływania $\mathrm{z}$ łatwością wyłapuje nasz słuch. Zauważalne są one $\mathrm{w}$ intonacyjnym wymiarze tekstu, w leksyce, przejawiają się w szczególnie nieprzejednanej logice przeprowadzania głównej nici myśli - zdemaskowania nieautentycznego i ogłoszenia prawdziwego, autentycznego bycia-ku-śmierci. Zostały już one zauważone w literaturze, czego przykładem może być Baudrillard, który pisał, że analityka fundamentalna jest „terroryzmem autentyczności, jaką dostarcza śmierć"24. Nie należy jednak niczego wyolbrzymiać - w rzeczywistości rola tych elementów nie jest tak wielka i, w całości, nie wpływają one destrukcyjnie na dyskurs autentycznie filozoficzny, poza jednym ważnym wyjątkiem. Podobnie jak w przypadku środków emocjonalnych, można wydzielić konkretne zadanie, w realizacji którego elementy nacisku wolicjonalnego koncentrują się w sposób szczególny i dają istotny wkład.

Na myśli mamy tym razem stwierdzenie o „wyjątkowości drogi i celu". Analityka egzystencjalna konsekwentnie stara się przedstawić to, czego nie wymaga filozofia, a wymaga praktyka duchowa, mianowicie odkrywaną przez nią drogę od „bycia powszedniego" do "zdecydowanego wybiegania w śmierć-jako-możliwość" jako obowiązkową i konieczną, jedyną i nieposiadającą alternatywy strategię samorealizacji bycia. Wcale nie tak trudno zauważyć, że to właśnie te właściwości stwierdzanych decyzji filozoficznych, ich wyjątkowość i koniczność, bardzo często pojawiają się jako bezpośredni bądź zawoalowany

${ }_{24}$ J. Baudrillard, L'Echange symbolique et la mort, Paris 1976, s. 229. akt wolicjonalny, jako tresura świadomości czytelniczej poprzez dodanie rozkazująco-hipnotyzujących wtrąceń typu zawsze, koniecznie, wyłacznie... (Por.: „Zdecydowaniu z konieczności przynależy nieokreśloność”, „Zdecydowanie jest zawsze zdecydowaniem aktualnego faktycznego Dasein" itp. - przykładów można znaleźć całą masę, ponieważ taki sposób uogólniania-wzmacniania jest charakterystyczny dla Heideggera). Już pod koniec konstrukcji, akt wolicjonalny, który potwierdza konieczność i moc obowiązującą wypracowanego stanowiska, przyjmuje retoryczne (z wyraźnym naciskiem) formy pytań: „Jeśli analityka kładzie u podstawy wybiegające zdecydowanie... to czy możliwość ta jest dowolna? Czyż sposób bycia, sposób, zgodnie z którym możność bycia Dasein odnosi się do swej śmierci, uchwycony jest przypadkowo? Czy bycie-w-świecie ma jakąś wyższa instancję swej możności bycia niż swoja śmierć?"25. Do tego fragmentu powinniśmy uczynić dwie uwagi. Po pierwsze, ostatnie spośród tych trzech pytań brzmi totalitarnie, jest ono, oczywiście, najbardziej sporne spośród tych trzech, a wręcz sporne w sposób jawny - a to właśnie ono wypowiadane jest ze szczególnym naciskiem, bo przecież wyróżnia się kursywą. Po drugie, powracając do tego tekstu w latach późniejszych, Heidegger odczuł potrzebę zmniejszenia ukrytej w nim pretensji. Pośród jego notatek do „Bycia i czasu”, które włączone zostały w późniejsze wydania książki, znajdujemy istotny dla nas przypis do pierwszego pytania: „Niestety nie tak; przecież „,bez dowolności" wcale jeszcze nie oznacza: koniecznie i obowiąz-

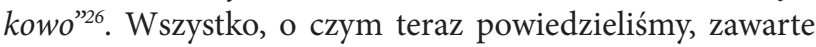
jest w tej lakonicznej autokorekcie. Zauważyliśmy przecież, że filozofia nie musi przekonywać do tego, iż konstruowana koncepcja egzystencjalna jest konieczna i obowiązuje wszystkich. Sprzymierzając się z samym autorem, możemy teraz podsumować, że filozofia nie tylko nie potrzebuje takich stwierdzeń, ale i ich nie uzasadnia. Ich obecność w analityce egzystencjalnej możemy nazwać daniną dla innego, niefilozoficznego dyskursu.

Efektem naszych rozważań są, mówiąc krótko, dwa dekonstrukcyjne wnioski. Po pierwsze, analityka fundamentalna, mimo posiadania swych filozoficznych zadań, staje się, implicite, realizacją paradygmatu Praktyki Duchowej. Należy przy tym pamiętać, że jest to realizacja egzotyczna, inwersja, w której miejsce Boga z tradycyjnych sposobów jej realizacji zajmuje - Trwoga, Śmierć i Nicośćc ${ }^{7}$. Ten

\footnotetext{
25 М. Хайдеггер,. Бытие и время, dz. суt., s. 313. Por. M. Heidegger Bycie i czas, dz. cyt., s. 409.

26 М. Хайдеггер, Бьэтие и время, dz. cyt., s. 444.

$27 \mathrm{Z}$ tego powodu, że dyskusja nad koncepcją Heideggera toczy się już dawno i jest dość popularna, jej powiązanie z inną popularną tematyką, teologicznymi odpowiednikami w analityce egzystencjalnej (zob. wyżej), pozwoliło bez problemu zauważyć dokonującą sie inwersję klasycznych struktur myśli religijnej. Ukażmy dla przykładu jedno charakterystyczne spostrzeżenie: „Heideggerowska teoria fundamentalnej sytuacji człowieka, w której wyraźnie są wpływy konkretnych rozdziałów z teologii chrześcijańskiej,... pojawia się jako zsekularyzowana, amoralizująca i nihilistyczna metafizyka nawrócenia... Ocalała cała struktura metafizyki nawrócenia, ale treść pojęć zmieniła się radykalnie... Struktura metafizyki nawrócenia jest starsza niż chrześcijaństwo, pochodzi ona, przynajmniej,
} 
nowy aspekt jej dyskursu nie jest bez znaczenia dla ogólnej interpretacji, ale i dla pytania o to, jakiego rodzaju rozwinięcie bądź przemianę ortodoksyjnej fenomenologii niesie ze sobą „Bycie i czas”. Po drugie, głoszone przez analitykę fundamentalną egzystencjalne wytyczne i strategia bycia w „Byciu i czasie” uznane zostały za „konieczne i obowiązujące wszystkich", bezalternatywne - co, jak sie okazało, nie jest wystarczająco uzasadnione i w co zwątpił później sam autor. Ponadto, nasze motywy były całkowicie przejrzyste. Analityka fundamentalna jest bezsprzecznie główną i najgłębszą koncepcją bądź konstytucją śmierci w myśli europejskiej od wielu wieków. Spróbowaliśmy nie tylko

z arystotelesowskiej teleologicznej koncepcji człowieka opisanej w „Etyce nikomachejskiej”. Paradoksalnie tę strukturę znajdujemy w „Byciu i czasie", gdzie struktura człowieka jest tak bardzo anty-teleologiczna, nihilistyczna i rozstrzygnięta (decisionistic) jak u Nietzschego. Paradoks polega na tym, że w teorii „Bycia i czasu”, zgodnie z którą intencjonalna struktura człowieka, z jednej strony, pod względem teleologicznym wymaga „autentycznego istnienia”, ale, z drugiej strony, to autentyczne istnienie jest całkowicie pozbawione treści. $\mathrm{W}$ tej paradoksalnej teorii spotykają się miedzy sobą dwie główne alternatywy współczesnego rozumienia człowieka i etyki: arystotelesowska i nietzscheańska" (N. O. Bernsen, Heidegger's Theory of Intentionality, Odense University Press, 1986, s. 184-185). Nie przypadkowo cytat został tak bardzo przedłużony, przedstawić jej strukturę, ale dokonaliśmy jej dekonstrukcji, w najbardziej konstruktywnym celu. Odkryliśmy to, że, z konkretnych przyczyn i z pomocą konkretnych środków, analityka ta nie tylko tworzyła wskazaną koncepcję, ale i dążyła do zbudowania wokół niej pancerza żelaznej niezaprzeczalności, który nie dopuszcza ani wariantów, ani sprzeciwów, obowiązującego wszystkich pancerza wyjątkowości. Zniszczywszy ten pancerz, dekonstrukcja otwiera możliwość innych decyzji i innych dróg.

\section{przekład ks. Łukasz Leonkiewicz}

ponieważ pomaga on nie tylko lepiej zrozumieć Heideggera, ale i praktykę duchową. Początkowe sformułowanie „metafizyka nawrócenia” jest wierne, ale nie głębokie; nie bierze ono pod uwagę hiedeggerowskiej próby „przezwyciężenia metafizyki” i nie ukazuje $\mathrm{w}$ analityce egzystencjalnej innego, bynajmniej nie metafizyczego paradygmatu Praktyki Duchowej. Natomiast to, co następuje po nim z pewnością jego dotyczy. Zauważony „paradoks”, aporia połączenia teleologizmu z telosem, który nie zawiera niczego (a dokładniej nie zawiera niczego empirycznego, ponieważ pod względem ontologicznym jest odmienny) jest jedną z cech kluczowych tego paradygmatu; i można zgodzić się, że właśnie Arystoteles i Nietzsche razem tworzą dla niego adekwatny (i sprzeczny wewnętrznie) kontekst.

Rozmiar artykułu: 1,3 arkusza wydawniczego 